Mycologia, 96(5), 2004, pp. 1074-1087.

(C) 2004 by The Mycological Society of America, Lawrence, KS 66044-8897

\title{
Phylogenetic and morphological assessment of five new species of Thozetella from an Australian rainforest
}

\author{
Barbara Paulus ${ }^{1}$ \\ Paul Gadek \\ School of Tropical Biology, James Cook University, \\ Cairns, QLD 4870, Australia \\ Kevin Hyde

\begin{abstract}
Centre for Research in Fungal Diversity, Department of Ecology and Biodiversity, University of Hong Kong, Pokfulam Road, Hong Kong, SAR, People's Republic of China
\end{abstract}

\begin{abstract}
During an investigation of saprobic microfungi in leaf litter from an Australian rainforest, five new species of Thozetella, namely $T$. acerosa, T. boonjiensis, T. falcata, T. gigantea and T. queenslandica, were identified and these are described and illustrated here. The morphology of specimens derived from cultures grown under different conditions and from natural substrata was compared. DNA sequence data of ITS regions within nuclear rDNA confirmed the morphological species concept and indicated that Thozetella species are anamorphs of the ascomycete genus Chaetosphaeria.
\end{abstract}

Key words: anamorphic fungi, Chaetosphaeria, Chaetosphaeriacae, key, microfungi, morphology, taxonomy, tropical fungi

\section{INTRODUCTION}

Thozetella O. Kuntze (1891) is a nomen novum for Thozetia Berk. et F. Mueller, which was antedated by Thozetia F. Mueller ex Bentham (Asclepiadaceae). Pirozynski and Hodges (1973) revised the genus and accepted four species. Since then, a further five species were added by Nag Raj (1976), Sutton and Cole (1983), Castañeda Ruiz (1984), Castañeda Ruiz and Arnold (1985) and Mercado Sierra et al (1997). The genus Thozetella is characterized by phialidic conidiogenesis, aseptate, hyaline, curved conidia with an unbranched setula on each pole, microawns and sporodochial, synnematal or effuse conidiomata (Pirozynski and Hodges 1973). Microawns are distinctive, sterile elements, which are produced from conidiophores and found in the spore mass. Their function

Accepted for publication January 14, 2004.

${ }^{1}$ Corresponding author. E-mail: Barbara.Paulus@jcu.edu.au is unknown but they might aid spore dispersal. The generic definition outlined above make the inclusion of T. ciliata (Mercado-Sierra et al 1997) doubtful, because this species lacks microawns and produces setae. Species are primarily saprobes of decaying plant material, including terrestrial litter, bark and palm fronds (Pirozynski and Hodges 1973, Yanna et al 2002), submerged wood (Sivichai et al 2002), and $T$. tocklaiensis was observed as a nonpathogenic root endophyte (Waipara et al 1996).

While revising the genus, Pirozynski and Hodges (1973) questioned the species concept in Thozetella because knowledge of variation with growth conditions and age was limited. Interpretation of species concepts in the genus is complicated by the fact that some species are known only from cultures and others only from fruiting bodies grown on natural substrata (Sutton and Cole 1983). Consequently, Sutton and Cole (1983) showed that characters of T. effusa can vary greatly depending on the substratum on which the fungus has grown.

During an investigation of the diversity of saprobic microfungi on leaf litter in an Australian rainforest (Paulus et al 2003), we isolated a number of specimens belonging in Thozetella. They could be assigned to five morphological groups based on microawn length and/or morphology. Two of these groups were known only from cultures, while the remaining three were available both as fruiting bodies from natural substrata and the cultures derived from them. Three of the morphological groups were differentiated mainly by the length of their microawns. To test whether they were indeed separate species rather than different stages of development of the same species or artifacts of cultural conditions, sequence analysis from internal transcribed spacer regions (ITS) of the nuclear ribosomal repeat (nrDNA) was undertaken. Sequence data also were used to clarify the placement of the genus among ascomycete lineages.

\section{METHODS}

Morphology of specimens from natural substrata and from culture.-Specimens of Thozetella were isolated after they sporulated on decaying leaves incubated in moist chambers (Booth 1971). In addition, spore suspensions were spread on $2 \%$ tap water agar containing $50 \mathrm{mg} \mathrm{L}^{-1}$ streptomycin and after 3-4 d small colonies were subcultured (Booth 
TABLE I. Collection and isolation details of Thozetella strains and herbarium specimens and the GenBank Accession number for DNA sequences of the ITS region

\begin{tabular}{|c|c|c|c|c|c|c|}
\hline Species name & $\begin{array}{c}\text { Collection } \\
\text { No. }\end{array}$ & $\begin{array}{c}\text { BRIP } \\
\text { No. }\end{array}$ & Substrata $^{a}$ & $\begin{array}{c}\text { Collection } \\
\text { details }^{\mathrm{b}}\end{array}$ & $\begin{array}{c}\text { Herbarium } \\
\text { specimen or } \\
\text { culture }^{c}\end{array}$ & $\begin{array}{c}\text { GenBank } \\
\text { accession } \\
\text { number }\end{array}$ \\
\hline T. acerosa & 5790 & 29319 & $\mathrm{Cm}$ & Site 1 & $\mathrm{C}(\mathrm{PF})$ & QY330996 \\
\hline T. boonjiensis & 2334 & 29318 & $\mathrm{Cm}$ & Site 1 & $\mathrm{C}(\mathrm{PF})$ & AY330994 \\
\hline T. boonjiensis & 2383 & 29316 & $\mathrm{Oh}$ & Site 1 & C $(\mathrm{PF})$ & AY330995 \\
\hline T. falcata & F568 & 29178 & $F p$ & Site 1 & $\mathrm{H}, \mathrm{C}(\mathrm{ss})$ & AY330999 \\
\hline T. falcata & F634 & 29192 & $\stackrel{\mathrm{Cm}}{\mathrm{m}}$ & Site 2 & $\mathrm{H}, \mathrm{C}$ (ss) & AY331000 \\
\hline T. falcata & F711 & 29201 & $\mathrm{Cm}$ & Site 2 & $\mathrm{H}, \mathrm{C}(\mathrm{ss})$ & AY331004 \\
\hline T. falcata & F715 & 29193 & $\mathrm{Cm}$ & Site 2 & $\mathrm{H}, \mathrm{C}(\mathrm{ss})$ & AY331003 \\
\hline T. gigantea & F709 & 29200 & $\mathrm{Cm}$ & Site 2 & $\mathrm{H}, \mathrm{C}(\mathrm{ss})$ & AY331001 \\
\hline T. gigantea & F712 & 29202 & $\mathrm{Cm}$ & Site 2 & $\mathrm{H}, \mathrm{C}$ (ss) & AY331002 \\
\hline T. queenslandica & F415 & 29164 & $\mathrm{Cm}$ & Site 1 & $\mathrm{H}, \mathrm{C}(\mathrm{ss})$ & AY330997 \\
\hline T. queenslandica & F612 & 29188 & $\mathrm{Cm}$ & Site 1 & $\mathrm{H}, \mathrm{C}$ (ss) & AY330998 \\
\hline
\end{tabular}

${ }^{\text {a }} \mathrm{Cm}=$ decaying leaves of Cryptocarya mackinnoniana, $\mathrm{Fp}=$ decaying leaves of Ficus pleurocarpa, Oh= decaying leaves of Opisthiolepis heterophylla.

${ }^{\text {b }}$ Site 1 = Old Boonjie Road, Topaz, Queensland, Australia; Site 2 = Brooke's Road, Millaa Millaa, Queensland, Australia.

${ }^{\mathrm{c}} \mathrm{H}=$ herbarium specimen, $\mathrm{C}=$ culture, $\mathrm{PF}=$ particle filtration, $\mathrm{ss}=$ cultures isolated via spore suspension and small colony isolation.

1971). Cultures also were isolated by particle filtration (Kirby and Webster 1990, Bills and Polishook 1994, Paulus et al 2003). Specimens and cultures are listed in TABLE I. Subcultures were grown on malt-yeast agar (MYA; Gams et al 1998) for colony description and on potato-carrot agar (PCA; Johnston and Booth 1983), which included small pieces of triple sterilized banana leaf (Matsushima 1971) and wheat straw to encourage sporulation. A total of 25 conidia, 25 microawns and 10 conidiophores mounted in $90 \%$ lactic acid were measured per specimen. The length of microawns of various shapes always was measured along its longest axis and at the widest point. Differences in microawn and conidial length of specimens grown on PCA and natural substrata were tested for T. falcata, T. gigantea and T. queenslandica using a Kruskal-Wallis Test (SPSS 2001). For the purpose of our study, we applied the definitions of Kirk (2001) for synnemata as erect fascicles of sometimes fused hyphae, which may bear a spore mass at the apex or at the apex and sides. Sporodochia are conidiomata in which the spore mass is supported by a superficial cluster of conidiophores and pseudoparenchyma. All cultures and specimens were deposited at the Queensland Plant Pathology Herbarium BRIP, Department of Primary Industries (TABLE I).

Response of type cultures to different growing conditions.Type strains were grown on cornmeal agar (CMA, Merck) and PCA, which contained a $20 \mathrm{~mm}^{2}$ piece of triple-sterilized banana leaf. Two replicate cultures on both media were subjected to different growing conditions. Temperature treatments were 20 and $25 \mathrm{C}$, and light treatment included incubation at $12 \mathrm{~h}$ light and $12 \mathrm{~h}$ dark cycles as well as at $24 \mathrm{~h}$ darkness. Conidiomatal configuration and growth rate were examined at weekly intervals for $3 \mathrm{wk}$, and microawn and conidial dimensions were recorded for each treatment after $2 \mathrm{wk}$. Differences in conidial and microawn length were tested for specimens grown on CMA under different conditions using a Kruskal-Wallis Test (SPSS 2001).

DNA extraction, amplification and sequencing.-Eleven strains of Thozetella (TABLE I) were incubated in $1.5 \mathrm{~mL}$ microfuge tubes containing $2 \%$ potato-carrot extract, to which $1 \%$ glucose had been added, for $14 \mathrm{~d}$ at room temperature. DNA was isolated using a protocol modified from Smith and Stanosz (1995). The resulting pellet was resuspended in $50 \mu \mathrm{L}$ double-sterilized distilled water $\left(\mathrm{ddH}_{2} \mathrm{O}\right)$.

DNA target amplification by polymerase chain reaction (PCR) was performed for the $5.8 \mathrm{~S}$ gene and the flanking ITS1 and ITS2 regions using the primers ITS1 and ITS4 (White et al 1990). All PCR reactions employed Taq DNA polymerase (Life Technologies) following the manufacturer's product protocol. The resulting PCR product was purified with an Ultraclean PCR Purification Kit (Mobio Laboratories Inc.) according to manufacturer's instructions.

Sequencing reactions were carried out with 30-90 ng of purified template DNA using the same primers mentioned above as sequencing primers and the Big Dye Terminator Cycle Sequencing Ready Reaction Kit (Perkin Elmer Applied Biosystems) according to manufacturer's instructions. Products were sequenced on an ABI-377 Prism Automated DNA Sequencer at the University of New South Wales, Australia. The nucleotide sequences were aligned and consensus sequences constructed using Sequence Navigator, version 1.0.1. (Applied Systems). All sequences reported in this article were deposited at GenBank (2003; http:// www.ncbi.nlm.nih.gov/Genbank/) and their GenBank accession numbers are given in TABLE I. Alignments and trees are accessible through TreeBase (2003; http://www. treebase.org/treebase/index.html) under the reference number SN1712. A BLAST search GenBank (2003; http:// www.ncbi.nlm.nih.gov/Genbank/) indicated high sequence similarity with members of the Chaetosphaeriaceae and an 
unidentified leaf litter ascomycete (GenBank Accession number AF502902).

DNA sequence analysis. - Two datasets were generated. The first aligned ITS rDNA sequences from two representative Thozetella species, T. gigantea and T. queenslandica, with the Chaetosphaeria dataset of Reblova and Winka (2000) available from TreeBase (2003; http://www.treebase.org/ treebase/index.html) under the reference number M1287. As a starting point, we accepted the alignment and outgroups proposed by Reblova and Winka (2000) but were more conservative in the analysis by treating gaps as missing data as opposed to fifth characters. The second dataset of the 11 available Thozetella sequences was used to examine the phylogeny of Thozetella. We chose to undertake a separate analysis because the alignment with the dataset of Reblova and Winka (2000) was ambiguous in places and characters had to be excluded. Based on the results of the first study, we selected Codinaeopsis gonytrichoides (Shearer et J.L. Crane) Morgan-Jones and Striatosphaeria codinaeaphora Samuels et E. Müll. outgroups. Indels initially were excluded from analysis, but to test the sensitivity of analysis to variable alignment, indels were scored as presence/absence. We were unable to use DNA of previously described Thozetella species for this study, which would have provided further information.

For both datasets, parsimony analysis was performed in PAUP* 4.0b10 (Swofford 2002). Gaps were treated as missing data. The computing scheme used for parsimony analysis was: heuristic search option with stepwise addition random, 1000 replications, tree bisection-reconnection branch swapping (TBR), MulTrees option in effect. A strict consensus tree was constructed from all most parsimonious trees and support for clades was estimated with a bootstrapping procedure (Felsenstein 1985) using 1000 replications. Pairwise genetic distances were calculated based on "uncorrected p" (transitions plus transversions/total number of nucleotides) as performed in PAUP*.

\section{RESULTS}

Taxonomy.-Microawn, conidioma and conidium sizes and their morphology from fruiting bodies derived from natural substrata and from cultures for new and previously described Thozetella species were summarized (TABLE II).

Thozetella Kuntze, Revis. gen. pl. (Leipzig) 2:873 (1891)

Type species: Thozetella nivea (Berk.) Kuntze, Revis. gen. pl. (Leipzig) 2:873 (1891)

Thozetella acerosa Paulus, P.Gadek et K.D. Hyde, sp.nov. $\quad$ FIG. 1A Ad fungos conidiales, hyphomycetes pertinens. Conidiomatae sporodochiae vel effusae, albae, 200-1500 $\mu \mathrm{m}$. Conidiophorae macronematae, brunnae, 2.5-4 $\mu \mathrm{m}$ latae. Cellulae conidiogenae pallidae brunneae, 12-20 × 2-4 $\mu \mathrm{m}$. Microaristae angulatae, $0-2$ septatae ad basi, apice acerosae et basi leviter obtusae, hyalinae, 60-80 $\times 5-4.5 \mu \mathrm{m}$ in PCA. Conidiae lunatae, unicellulariae, hyalinae, $14-20 \times 2-3 \mu \mathrm{m}$ in PCA, laeves et utrinque solo appendice, filiformi praedita, 6-7 $\mu \mathrm{m}$ longa.

Etymology. "acerasa" referring to the needle-like apices of the microawns.

Colonies cream and light brown, flat, woolly to subfelty, margin incised and indistinct. Conidiomata sporodochial or effuse, superficial, sessile, forming a convex or flat hymenium, topped by a moist spore mass, 200-1500 $\mu \mathrm{m}$ diam. Conidiophores macronematous, brown, irregularly cylindrical, branched, arising from a basal plate, 2.5-4 $\mu \mathrm{m}$ wide. Conidiogenous cells monophialidic, integrated, determinate, terminal, light brown, irregularly cylindrical, with no or minute collarette, periclinal wall thickened, 12-20 $\times$ 2-4 $\mu \mathrm{m}$. Microawns produced from conidiophores, predominantly L-shaped, basal part thin-walled and hyaline, with 0-2 septa depending on growing conditions (TABLE III), apical part acerose and slightly undulating, smooth, thick-walled with the upper portion becoming solid, refractive, 60-80 $\times 3.5-4.5 \mu \mathrm{m}$ in PCA. Conidia lunate, aseptate, finely guttulate, hyaline and smooth, 14-20 × 2-3 $\mu \mathrm{m}$ in PCA, with one filiform setula at each end, 6-7 $\mu \mathrm{m}$ long.

Specimens examined. AUSTRALIA, QUEENSLAND: Atherton Tablelands, Topaz, Old Boonjie Road, on decaying leaves of Cryptocarya mackinnoniana, 8 Sep 2001, B. Paulus and C. Pearce, BP5970, HOLOTYPE: BRIP 29319.

Commentary. Thozetella acerosa resembles $T$. nivea in microawn shape. Our isolate differs in having shorter and narrower conidia and longer microawns than reported for $T$. nivea. In addition, our specimens have 0-2 septa at the basal part of the microawns at $25 \mathrm{C}$ while microawns of T. nivea are aseptate. Two other species described below, namely $T$. boonjiensis and T. gigantea, also have L-shaped microawns and form sporodochia. Mature specimens of T. gigantea are distinguished easily because they have much longer microawns. Mean values of microawn and conidial length, as well as the presence or absence of septation in microawns, clearly differentiate between T. acerosa and T. boonjiensis.

Thozetella boonjiensis Paulus, P.Gadek et K.D. Hyde,

sp. nov. FIG. 1B-E

Ad fungos conidiales, hyphomycetes pertinens. Coloniae cremeae et fuscae Conidiomatae sporodochiae vel effusae, 120-250 × 300-400 $\mu \mathrm{m}$. Conidiophorae macronematae, brunnae, ramosae, $1.5-3 \mu \mathrm{m}$ latae. Cellulae conidiogenae pallidae brunneae, $15-20 \times 1.5-2.5 \mu \mathrm{m}$. Microaristae angulatae, aseptatae, apice acerosae, refractivae et basi leviter obtusae, hyalinae, 48-75 $\times 3-5 \mu \mathrm{m}$ in PCA. Conidiae lunatae, unicellulariae, hyalinae, 10-15 $\times 2-3 \mu \mathrm{m}$ in PCA, laeves et utrinque solo appendice, filiformi praedita, $5-8 \mu \mathrm{m}$ longa. 
Paulus et AL: Five NeW SPEcies of Thozetella

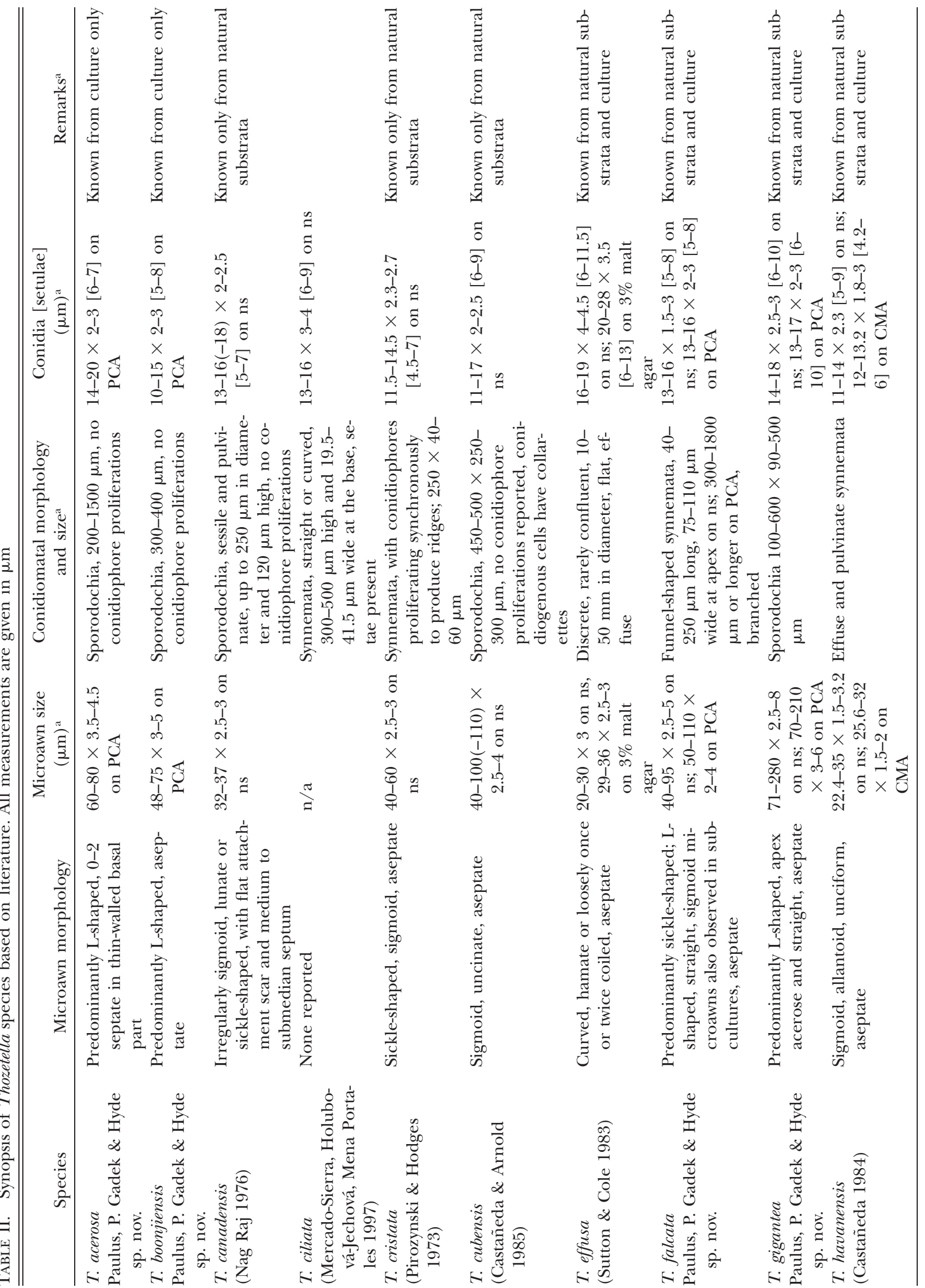


Etymology. "boonjiensis" referring to the place of collection near the Old Boonjie Road in northern Queensland.

Colonies cream and pale brown, subfelty, slimy, reverse pale brown. Conidiomata sessile sporodochia, 300-400 $\mu \mathrm{m}$ diam, or flat effuse development of conidiophores. Conidiophores macronematous, brown, cylindrical, branched, arising from a basal plate of cells, 1.5-3 $\mu \mathrm{m}$ wide. Conidiogenous cells monophialidic, integrated, determinate, terminal, light brown, irregularly cylindrical, lacking an apical collarette, no or slight periclinal wall thickening, 15-20 $\times 1.5-2.5 \mu \mathrm{m}$. Microawns produced from conidiophores, predominantly L-shaped, aseptate, smooth, apical part acerose, straight or slightly undulating, thick-walled, refractive, basal part thin-walled, hyaline, aseptate, $48-75 \times 3-5 \mu \mathrm{m}$ on PCA. Conidia lunate, continuous, finely guttulate or eguttulate, hyaline, smooth, 10-15 $\times 2-3 \mu \mathrm{m}$ on PCA, supplied with a single, 5-8 $\mu \mathrm{m}$ long, filiform setula at each end.

Specimens examined. AUSTRALIA, QUEENSLAND, Atherton Tablelands, Topaz, Old Boonjie Road, on decaying leaves of C. mackinnoniana, 11 Mar 2001, B. Paulus and C. Pearce, BP2334, HOLOTYPE: BRIP 29318. AUSTRALIA, QUEENSLAND: Atherton Tablelands, Topaz, Old Boonjie Road, on decaying leaves of Opisthiolepis heterophylla, 11 Mar 2001, B. Paulus and C. Pearce, BP2383, BRIP 29316.

Commentary. Thozetella boonjiensis resembles $T$. tocklaiensis in microawn shape and conidial dimensions. Our isolates differ in having longer microawns (48-75 $\times 3-5 \mu \mathrm{m}$ rather than $18-38[-44] \times 1.5-5$ $\mu \mathrm{m})$ and in producing sporodochia or effuse conidiomata rather than the synnemata reported for cultures of T. tocklaiensis. Two other species described here, namely T. acerosa and T. gigantea, also have Lshaped microawns and form sporodochia. Mature specimens of T. gigantea are easily distinguished because they have much longer microawns. Young specimens of $T$. gigantea may show an overlap in microawn dimensions with $T$. boonjiensis but can be differentiated because they have longer conidia. Mean values of microawn and conidial length, as well as the presence or absence of septation in microawns clearly differentiate between T. acerosa and T. boonjiensis.

Thozetella falcata Paulus, P. Gadek et K.D. Hyde, sp. nov. FIG. 1F-L

Ad fungos conidiales, hyphomycetes pertinens. Conidiomatae synnematae, brunneae, 40-250 × 12-35 $\mu \mathrm{m}$ ad basim et $75-110 \mu \mathrm{m}$ ad apicem in foliis dejectis, 300-1800 $\times 12-80 \mu \mathrm{m}$ ad basim et $120-300 \mu \mathrm{m}$ ad apicem in PCA. Conidiophorae macronematae, brunnae, 1.5-3 $\mu \mathrm{m}$ latae. Cellulae conidiogenae pallidae brunneae, 6-19 $\times 2-3 \mu \mathrm{m}$. Microaristae hamatae, angulatae, sigmoidae vel rectae, apice crassitunicatae, refractivae et basi leviter obtusae, hyali- 

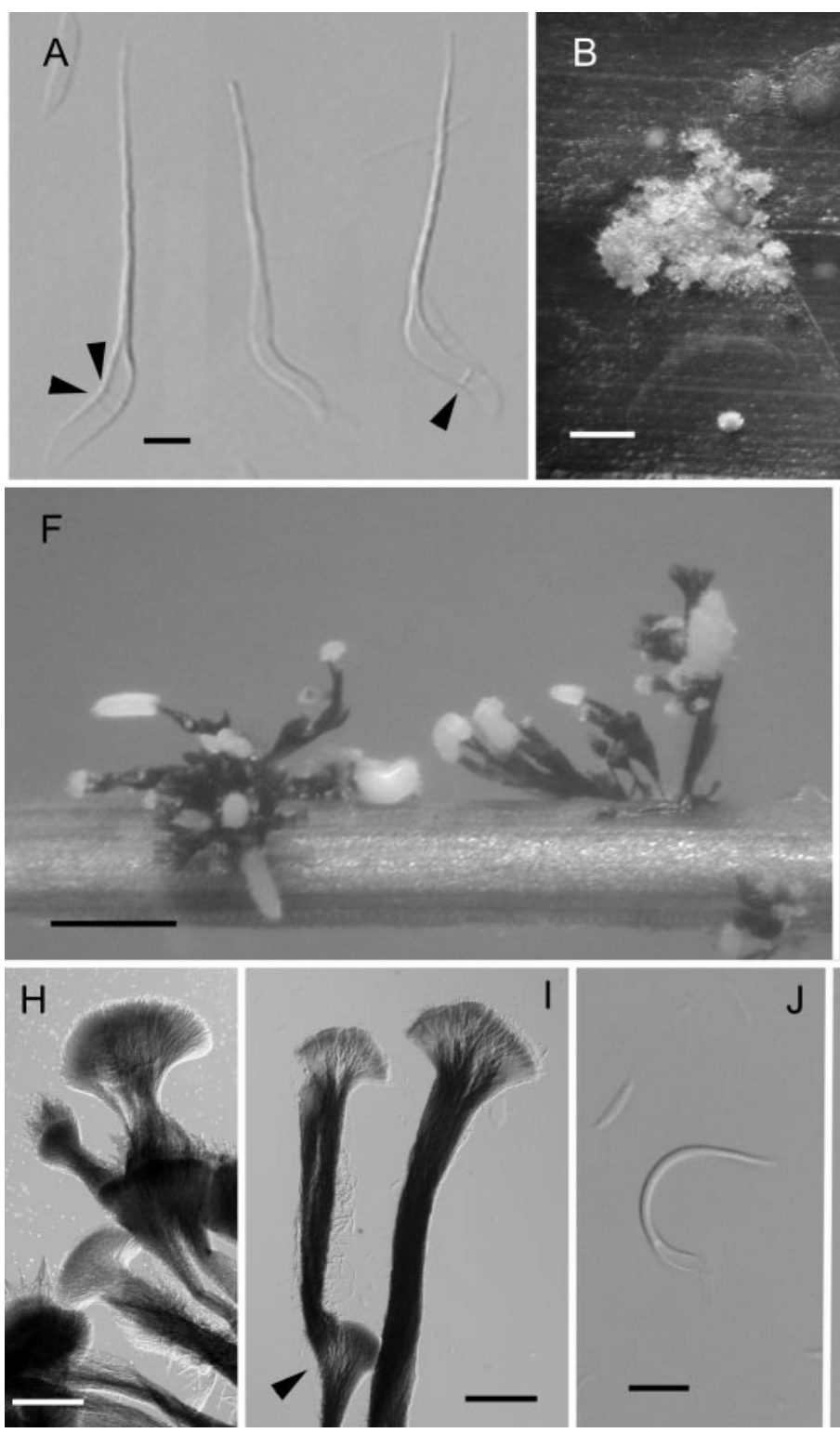
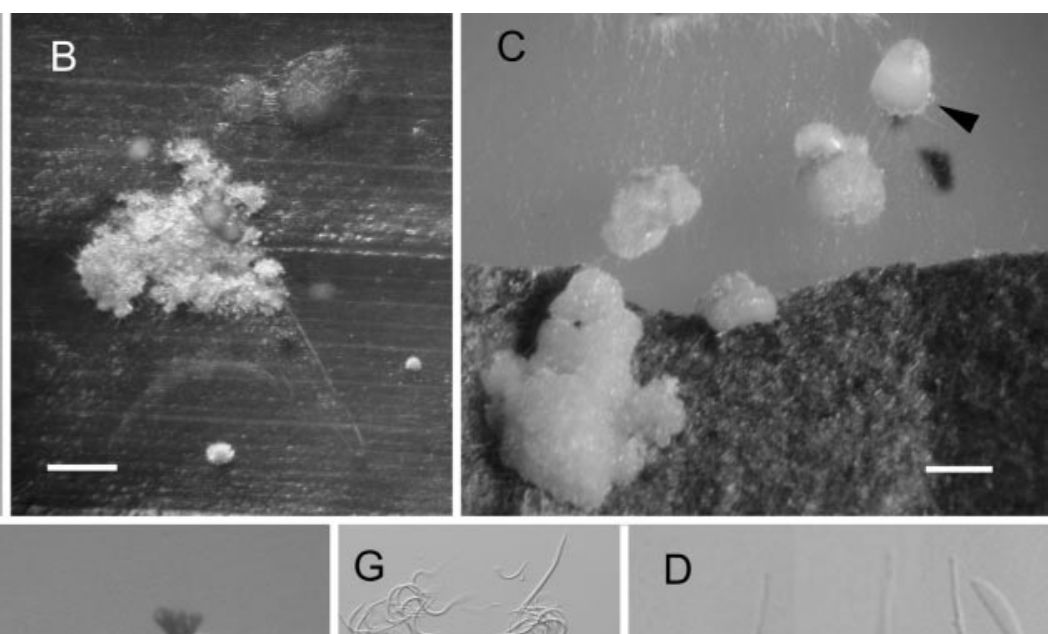

D
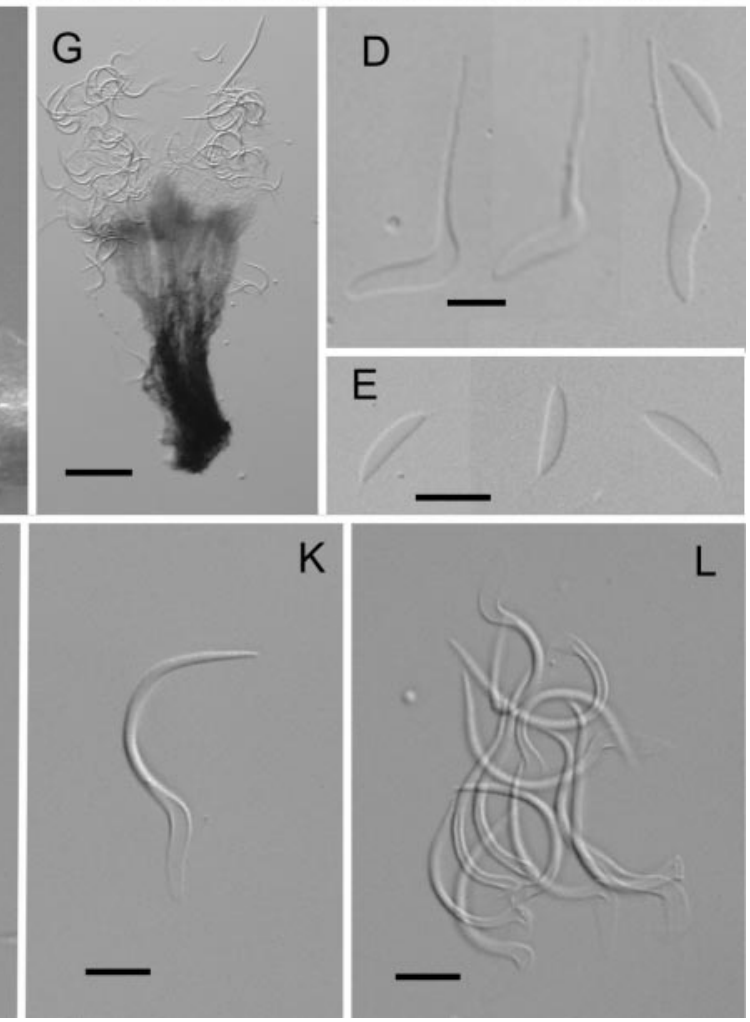

FIG. 1. A. Thozetella acerosa: microawns (arrow heads indicate septa). B-E. Thozetella boonjiensis. B. effuse conidiophores on sterilized banana leaf in PCA. C. single sporodochia (arrow head) and coalescing sporodochia. D. microawns. E. conidia. F-L. Thozetella falcata. F. branching synnemata growing on sterilized wheat straw in PCA. G. synnema from natural substratum. H-I. elongated synnemata in PCA (arrow head indicates branching point). J-L. microawns. Bars: A, D, E = 10 $\mu$ m; I, $\mathrm{J}, \mathrm{K}, \mathrm{L}=20 \mu \mathrm{m} ; \mathrm{C}, \mathrm{G}, \mathrm{H}=300 \mu \mathrm{m} ; \mathrm{B}, \mathrm{F}=1 \mathrm{~mm}$.

nae, unicellularae, $40-95 \times 2.5-5 \mu \mathrm{m}$ in foliis dejectis, 50 $110 \times 2-4 \mu \mathrm{m}$ in PCA. Conidiae lunatae, unicellulariae, hyalinae, $13-16 \times 1.5-3 \mu \mathrm{m}$, laeves et utrinque solo appendice, filiformi praedita, $5-8 \mu \mathrm{m}$ longa.

Etymology. "falcata" referring to the sickle-shaped microawns.

Colonies hyaline with brown, concentric rings, flat, no aerial mycelium, synnemata formed in concentric rings on agar surface and on banana leaf. Conidiomata funnel-shaped synnemata, brown to dark brown, abundant on leaf, 40-250 $\mu \mathrm{m}$ long, 12-35 $\mu \mathrm{m}$ wide at base and $75-110 \mu \mathrm{m}$ at apex on natural substrata, in PCA much more elongated (300-1800 $\mu \mathrm{m}$ long, 12-80 $\mu \mathrm{m}$ wide at base and 120-300 $\mu \mathrm{m}$ at apex), some synnemata forming branches. Conidiophores macronematous, brown, paling toward apex, irregularly cylindrical, densely compacted along synnematal axis, branched, 1.5-3 $\mu \mathrm{m}$ wide. Conidiogenous cells monophialidic, integrated, determinate, terminal, light brown, packed into tight palisades, irregularly cylindrical with bluntly rounded apex, lacking an apical collarette, periclinal wall thickened, 6-19 × 2-3 $\mu \mathrm{m}$. Microawns predominantly sickle-shaped in specimens on natural substrata; L-shaped, sigmoid and 
TABLE III. Percentage of microawns in Thozetella acerosa that formed septa under different growing conditions

\begin{tabular}{|c|c|c|c|c|c|c|}
\hline \multirow[b]{2}{*}{ Media } & \multirow[b]{2}{*}{ Temperature } & \multirow[b]{2}{*}{ Light } & \multicolumn{4}{|c|}{ No. of septa } \\
\hline & & & 0 & 1 & 2 & 3 \\
\hline \multirow[t]{4}{*}{ CMA } & $20 \mathrm{C}$ & light/dark & 95 & 5 & & \\
\hline & & dark & 40 & 50 & 5 & 5 \\
\hline & $25 \mathrm{C}$ & light/dark & 35 & 55 & 5 & 5 \\
\hline & & dark & 25 & 65 & 5 & 5 \\
\hline \multirow[t]{4}{*}{ PCA } & $20 \mathrm{C}$ & light/dark & 100 & & & \\
\hline & & dark & 90 & 10 & & \\
\hline & $25 \mathrm{C}$ & light/dark & 45 & 45 & 10 & \\
\hline & & dark & 40 & 50 & 5 & 5 \\
\hline
\end{tabular}

straight microawns also were observed in subcultures in addition to sickle-shaped microawns, 40-95 $\times 2.5-$ $5 \mu \mathrm{m}$ on natural substrata, $50-110 \times 2-4 \mu \mathrm{m}$ on PCA. Conidia lunate, aseptate, finely guttulate or eguttulate, hyaline, smooth, 13-16 × 1.5-3 $\mu \mathrm{m}$ on natural substrata, $13-16 \times 2-3 \mu \mathrm{m}$ on PCA, provided with a single, filiform setula at either pole, 5-8 $\mu \mathrm{m}$ long.

Specimens examined. AUSTRALIA, QUEENSLAND: Atherton Tablelands, Millaa Millaa, Brooke's Road, on decaying leaves of C. mackinnoniana, 28 May 2002, B. Paulus and I.G. Steer, BP F715, HOLOTYPE: BRIP29193. AUSTRALIA, QUEENSLAND: Atherton Tablelands, Topaz, Old Boonjie Road, on decaying leaves of Ficus pleurocarpa, 23 Mar 2002, B. Paulus and I.G. Steer, BP F568, BRIP 29178. AUSTRALIA, QUEENSLAND, Atherton Tablelands, Millaa Millaa,
Brooke's Road, on decaying leaves of C. mackinnoniana, 28 May 2002, B. Paulus and I.G. Steer, BP F634, BRIP 29192. AUSTRALIA, QUEENSLAND: Atherton Tablelands, Millaa Millaa, Brooke's Road, on decaying leaves of C. mackinnoniana, 21 Jun 2002, B. Paulus and I.G. Steer, BP F711, BRIP 29201.

Commentary. Thozetella falcata, T. cristata, T. radicata and T. tocklaiensis all produce synnemata. Thozetella falcata is also similar to $T$. cristata and $T$. radicata in microawn shape and in conidial dimensions. However, T. falcata differs from these two species in having considerably longer microawns on natural substrata and in culture. In addition, T. falcata differs from $T$. radicata in having branched and longer synnemata. Conidiomata of $T$. falcata are also different from those of $T$. cristata, in which conidiophores proliferate simultaneously to form visible ridges. In addition, Thozetella cristata forms consistently cylindrical synnemata while those in $T$. falcata are funnelshaped. The length and morphology of synnemata in T. tocklaiensis are similar to those of T. falcata, however, these two fungal taxa differ in microawn morphology and size.

Thozetella gigantea Paulus, P.Gadek et K.D. Hyde, sp. nov. FIG. 2J-M

Ad fungos conidiales, hyphomycetes pertinens. Conidiomatae sporodochiae, 100-600 × 90-500 $\mu \mathrm{m}$. Conidiophorae macronematae, brunnae, 2.5-4 $\mu \mathrm{m}$ latae. Cellulae conidiogenae pallidae brunneae, $12-20 \times 2-4 \mu \mathrm{m}$. Microar-
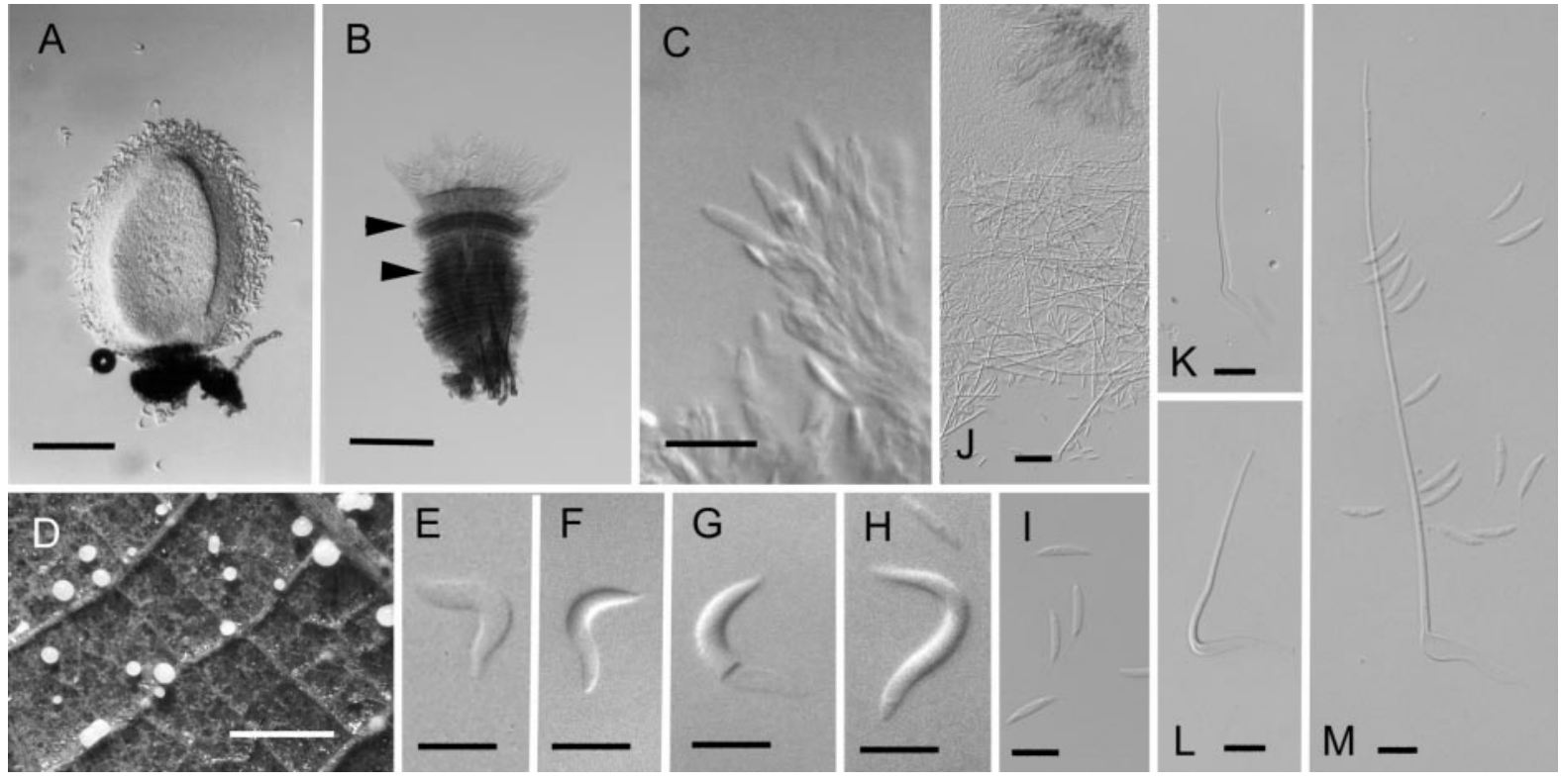

Fig. 2. A-I. Thozetella queenslandica. A. sporodochium from natural substratum. B. older sporodochium from natural substratum. Arrow heads indicate ridges formed by conidiophore proliferation. C. conidiophores. D. sporodochia on abaxial surface of Cryptocarya mackinnoniana leaf. E-H. microawns. I. conidia. J-M. Thozetella gigantea. J. part of sporodochium, spore mass and microawns of subcultures on PCA. K, L. microawns. M. microawn and conidia. Bars: A, B = $100 \mu \mathrm{m}$; H-I = $25 \mu \mathrm{m}$. C, E-F, J-M = $10 \mu \mathrm{m} ; \mathrm{D}=1 \mathrm{~mm}$. 


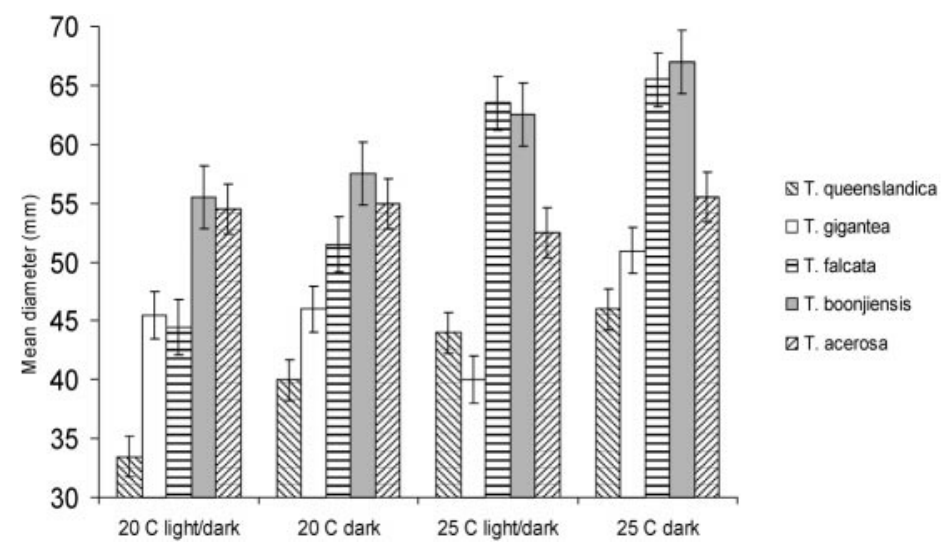

FIG. 3. Mean diameter of Thozetella cultures incubated 3 wk on CMA under different light and temperature regimes.

istae angulatae, apice acerosae et basi leviter obtusae, hyalinae, unicellularae, 71-280 $\times 2.5-8 \mu \mathrm{m}$ in foliis dejectis, 70$210 \times 3-6 \mu \mathrm{m}$ in PCA. Conidiae lunatae, unicellularae, hyalinae, $14-18 \times 2.5-3 \mu \mathrm{m}$ in substr. nat. et $13-17 \times 2-3$ $\mu \mathrm{m}$ in PCA, laeves et utrinque solo appendice, filiformi praedita, 6-10 $\mu \mathrm{m}$ longa.

Etymology. "gigantea" referring to the size of microawns.

Colonies cream with brown radial lines developing, subfelty, fast growing. Conidiomata sporodochial, superficial, sessile, forming a convex or flat hymenium, topped by a moist, white spore mass with long, straight needle-like apices of microawns protruding from it, few sporodochia produced per leaf, 100-600 $\times$ 90-500 $\mu \mathrm{m}$. Conidiophores macronematous, brown, irregularly cylindrical, branched, arising from a basal plate, non-proliferating, 2.5-4 $\mu \mathrm{m}$ wide. Conidiogenous cells monophialidic, integrated, determinate, terminal, light brown, irregularly cylindrical, collarette missing, periclinal wall thickened, 12-20 $\times$ 2-4 $\mu \mathrm{m}$. Microawns produced from conidiophores, predominantly L-shaped, basal part thin-walled, hyaline, continuous, long apical part acerose, smooth, straight, thick-walled with the upper portion becoming solid, narrowing down to less than $0.5 \mu \mathrm{m}$ wide, refractive, $71-280 \times 2.5-8 \mu \mathrm{m}$ on natural substrata, $70-210 \times 3-6 \mu \mathrm{m}$ on PCA. Conidia lunate, aseptate, finely guttulate, hyaline, smooth, slightly truncate on basal pole, $14-18 \times 2.5-3 \mu \mathrm{m}$ on natural substrata and 13-17 $\times 2-3 \mu \mathrm{m}$ on PCA, with a single, 6-10 $\mu \mathrm{m}$ long, filiform setula at each end.

Specimens examined. AUSTRALIA, QUEENSLAND: Atherton Tablelands, Millaa Millaa, Brooke's Road, on decaying leaves of C. mackinnoniana, 28 May 2002, B. Paulus and I.G. Steer, BP F712, HOLOTYPE: BRIP 29202. AUSTRALIA, QUEENSLAND: Atherton Tablelands, Millaa Millaa, Brooke's Road, on decaying leaves of C. mackinnoniana, 28 May 2002, B. Paulus and I.G. Steer, BP F709, BRIP29200.

Commentary. Thozetella gigantea resembles T. nivea, T. acerosa and T. boonjiensis in the production of sporodochia and in microawn shape. It differs in having considerably longer microawns on natural substrata and in culture.

Thozetella queenslandica Paulus, P.Gadek et K.D. Hyde, sp. nov. FIG. 3A-I

Ad fungos conidiales, hyphomycetes pertinens. Conidiomatae sporodochiae superficialiae, 200-250 × 50-125 $\mu \mathrm{m}$. Conidiophorae macronematae, brunnae, ramosae. Cellulae conidiogenae pallidae brunneae vel subhyalinae, 10$25 \times 1.5-2.5 \mu \mathrm{m}$. Microaristae hamatae, sigmoidae, lavae vel verrucosae ad apicem, 24-33 × 2-3.5 $\mu \mathrm{m}$. Conidiae lunatae, unicellularae, hyalinae, $10-12 \times 1.5-2.5 \mu \mathrm{m}$, laevae et utrinque solo appendice, filiformi praedita, 3-6 $\mu \mathrm{m}$ longa.

Etymology. "queenslandica" referring to the state of Queensland in Australia where this fungus was first isolated.

Colonies cream to gray, woolly, reverse with gray concentric rings. Conidiomata superficial, sessile sporodochia, 200-250 × 50-125 $\mu \mathrm{m}$, forming a flat or convex hymenium on a dark brown, stromatic base, which bears a globose, ovoid or otherwise shaped white mass of conidia and microawns; some sporodochia produce dark brown transverse ridges, each representing an area of synchronous proliferation of conidiophores. Conidiophores macronematous, brown, irregularly cylindrical, branched, compact at base, more or less free toward of upper part of sporodochium. Conidiogenous cells monophialidic, integrated, determinate, terminal, light brown to subhyaline, irregularly cylindrical, without collarettes, periclinal wall thickened, $10-25 \times 1.5-2.5 \mu \mathrm{m}$. Microawns produced from conidiophores, predominantly hamate, rarely sigmoid, refractive, with a smooth or verrucose apex, 24-33 $\times 2-3.5 \mu \mathrm{m}$ on natural substrata, $21-34 \times 2-4 \mu \mathrm{m}$ on PCA. Conidia lunate, continuous, hyaline, eguttulate, smooth, 10-12 $\times 1.5-2.5 \mu \mathrm{m}$ on natural substrate and 9-12 $\times 1.5-$ 
TABLE IV. Sporulation of type cultures after 2 wk incubation on two media and under different conditions

\begin{tabular}{|c|c|c|c|c|c|}
\hline & & \multicolumn{2}{|c|}{$20 \mathrm{C}$} & \multicolumn{2}{|c|}{$25 \mathrm{C}$} \\
\hline & & Light/dark & Dark & Light/dark & Dark \\
\hline \multirow[t]{5}{*}{ CMA } & T. acerosa & sp \& eff + & $\mathrm{sp}++$ & $\mathrm{sp}++$ & $\mathrm{sp}+++$ \\
\hline & T. boonjiensis & - & $\operatorname{sp}(+)$ & sp \& eff + & - \\
\hline & T. falcata & sy ++ & sy ++ & sy ++ & sy ++ \\
\hline & T. gigantea & $\operatorname{sp}(+)$ & - & $\mathrm{sp}+$ & $\mathrm{sp}+$ \\
\hline & T. queenslandica & $\operatorname{sp}(+)$ & $\mathrm{sp}+$ & $\mathrm{sp}+$ & - \\
\hline \multirow[t]{5}{*}{ PCA } & T. acerosa & sp \& eff ++ & sp \& eff ++ & sp \& eff ++ & $\mathrm{sp}++$ \\
\hline & T. boonjiensis & & & sp \& eff, sy + & \\
\hline & T. falcata & sy ++ & sy + & sy ++ & sy ++ \\
\hline & T. gigantea & - & - & $(\operatorname{sp}(+)$ & - \\
\hline & T. queenslandica & $\mathrm{sp}+$ & $\mathrm{sp}+$ & $\mathrm{sp}++$ & - \\
\hline
\end{tabular}

$\mathrm{sp}=$ sporodochia.

sy $=$ synnemata.

eff $=$ effuse layer of conidiophores.

- none, $(+)=$ few, $+=$ some, $++=$ many, $+++=$ abundant sporulating structures .

2.5 $\mu \mathrm{m}$ on PCA, provided with a single filiform setula at each end, 3-6 $\mu \mathrm{m}$ long.

Specimens examined. AUSTRALIA, QUEENSLAND: Atherton Tablelands, Topaz, Old Boonjie Road, on decaying leaves of C. mackinnoniana, 28 May 2002, B. Paulus and I.G. Steer, BP F612, HOLOTYPE: BRIP 29188. AUSTRALIA, QUEENSLAND: Atherton Tablelands, Topaz, Old Boonjie Road, on decaying leaves of C. mackinnoniana, $23 \mathrm{Mar}$ 2002, B. Paulus and I.G. Steer, BP F415, BRIP 29164.

Commentary. Thozetella queenslandica can be differentiated from other known species of Thozetella on the basis of its distinctive, short hamate microawns and the production of sporodochia, which show proliferation ridges. The microawns of $T$. queenslandica overlap in length with those of T. effusa and T. havanensis, but these species differ from T. queenslandica in both microawn and conidiomatal morphology.

Growth and sporulation of cultures under different growing conditions. - Although some variation of microawn and conidial lengths were observed in specimens grown on PCA and on natural substrata, these were not found to be significant $(\mathrm{df}=1 ; P=0.524$ and $\mathrm{df}=1 ; P=0.727$, respectively). Similarly, no significant differences in microawn and conidial lengths were noted for cultures grown on different media $(\mathrm{df}=1 ; P=0.457$ and $\mathrm{df}=1 ; P=0.583$, respectively). Microawn length also did not differ significantly for cultures grown under different light and temperature treatments $(\mathrm{df}=3 ; P=0.968)$. In contrast, conidial length differed significantly under different cultures conditions ( $\mathrm{df}=3 ; P=0.002$ ). Examination of raw data (not shown) revealed that conidia of $T$. gigantea were markedly longer at $25 \mathrm{C}$ compared to $20 \mathrm{C}$ (18.3 and $15.2 \mu \mathrm{m}$ respectively). The mean diameter of type strains incubated $3 \mathrm{wk}$ on CMA at different temperature and light regimes is given in Fig. 3. All cultures grew well on CMA and PCA, and generally similar patterns were observed on both media. One group, which included T. queenslandica, T. falcata and T. boonjiensis, appeared to grow faster at $25 \mathrm{C}$. In contrast, T. gigantea and T. acerosa appeared to favor $20 \mathrm{C}$ with the slower growth rate observed at $25 \mathrm{C}$ with light/dark cycles.

A summary of sporulation patterns after $2 \mathrm{wk}$ is provided in TABLE IV. Thozetella acerosa and T. falcata commenced sporulation in the first week and continued to sporulate profusely on both media and under all conditions. Scant sporulation from the second week onward was observed for $T$. gigantea and $T$. boonjiensis. Thozetella queenslandica sporulated well under a relatively wide range of conditions but did not form fruiting structures at $25 \mathrm{C}$ in the dark on either medium (TABLE IV). With some exceptions, conidiomata of all species appeared to be consistent in their basic configuration over the $3 \mathrm{wk}$ observation period. Exceptions included the development of effuse conidiophores in addition to sporodochia in $T$. acerosa and $T$. boonjiensis under some conditions. Thozetella boonjiensis also developed cream to light brown, submerged synnemata at $25 \mathrm{C}$ on PCA when exposed to light/dark cycles. At $25 \mathrm{C}$ synnemata of T. falcata were submerged in the agar.

\section{KEY TO THE DESCRIBED SPECIES OF THOZETELLA}

1. microawns present $\ldots \ldots \ldots \ldots \ldots \ldots \ldots \ldots . \ldots \ldots$

1. microawns absent $\ldots \ldots \ldots \ldots \ldots \ldots$. ciliata

2. microawns predominantly L-shaped ....... 3

2. microawns not L-shaped or variously shaped ${ }^{2}$. 6

3. microawns $0-2$ septate, $60-80 \times 3.5-4.5 \mu \mathrm{m}$ (mean $72 \times 3.9 \mu \mathrm{m}) \ldots \ldots \ldots \ldots \ldots \ldots$. acerosa

3. microawns aseptate $\ldots \ldots \ldots \ldots \ldots \ldots$

4. microawns very long, 70-280 $\mu \mathrm{m} \times 2.5-8 \mu \mathrm{m}$ 
(mean $153.8 \times 5 \mu \mathrm{m}$ on natural substrata, 132.4 $\times 4.2 \mu \mathrm{m}$ on PCA) $\ldots \ldots \ldots \ldots$ T. gigantea 4. microawns shorter than $75 \mu \mathrm{m} \ldots \ldots \ldots \ldots 5$

5. conidia $(17.5-) 21(-24) \times 3-3.8 \mu \mathrm{m}$, microawns 50 $70 \times 3-4 \mu \mathrm{m}$, microawn apex undulating or geniculate ................. nivea

5. conidia 10-15 $\times 2-3 \mu \mathrm{m}$, microawns $48-75 \times 3-5$ $\mu \mathrm{m}($ mean $60.1 \times 3.6 \mu \mathrm{m})$, microawn apex straight or slightly undulating ........ T. boonjiensis 6. microawns predominantly sickle-shaped, uncinate, hamate or otherwise strongly curved ... 7 6. microawns predominantly straight, sigmoid or any other shape .............. 11

7. conidiomata predominantly synnematous ....... 8

7. conidiomata predominantly sporodochial .... 10

8. synnemata cylindrical, proliferating conidiophores form ridges, microawns 40-60 × 2.5-3 $\mu \mathrm{m}$, conidia $11.5-14.5 \times 2.3-2.7 \mu \mathrm{m} \ldots$. T. cristata

8. synnemata funnel-shaped, conidiophores nonproliferating ................ 9

9. microawns $40-95 \times 2.5-5 \mu \mathrm{m}($ mean $59.9 \times 3.6 \mu \mathrm{m}$ on natural substratum, $77.2 \times 3.3 \mu \mathrm{m}$ in PCA), conidia $13-16 \times 1.5-3 \mu \mathrm{m}$, synnemata branching $\ldots$. . . . . falcata

9. microawns $30-60 \times 3-4.5 \mu \mathrm{m}$, conidia $11-13 \times 2-$ $2.5 \mu \mathrm{m} \ldots \ldots \ldots \ldots \ldots \ldots \ldots$. . radicata 10. microawns $21-34 \times 2-4 \mu \mathrm{m}$ (mean $27.9 \times 3 \mu \mathrm{m}$ on natural substrata, $26.9 \times 2.9 \mu \mathrm{m}$ on PCA), proliferation ridges on sporodochia, conidia 9$12 \times 1.5-2.5 \mu \mathrm{m} \ldots \ldots \ldots \ldots$ T. queenslandica 10. microawns $40-110 \times 2.5-4 \mu \mathrm{m}$, conidia 11-17 $\times 2-2.5 \mu \mathrm{m}$, sporodochia without proliferation ridges ............. T. cubensis

11. conidiomata effuse, never sporodochial or synnematous, microawns $20-30 \times 3 \mu \mathrm{m}$, conidia 16-19 $\times$ $4-4.5 \mu \mathrm{m} \ldots \ldots \ldots \ldots \ldots \ldots \ldots$ T. effusa

11. conidiomata sporodochial or synnematous ..... 12 12. conidiomata sporodochial, microawns $32-37 \times$ 2.5-3 $\mu \mathrm{m}$, conidia 13-16(-18) $\times 2-2.5 \mu \mathrm{m} \ldots$ $\ldots \ldots \ldots \ldots \ldots \ldots \ldots \ldots$ T. canadensis

12. conidiomata synnematous . . . . . . . . 13

13. microawns variously shaped ${ }^{2}$, bulbous base, acerose apex, straight, undulate, uncinate or bent 18-38 $(-44) \times 1.5-4 \mu \mathrm{m}$, conidia $9-13(-18) \times 1.5-3 \mu \mathrm{m}$ $\ldots \ldots \ldots \ldots \ldots \ldots \ldots$ T. tocklaiensis

13. microawns with \pm uniform width, sigmoid, allantoid, uncinate, verruculose, $22.4-35 \times 1.5-3.2 \mu \mathrm{m}$, conidia 11-14 $\times 2.3 \mu \mathrm{m}$, conidiomata synnematous or effuse ............ havanensis

ITS DNA sequence analyses. - The aligned dataset of Thozetella and Chaetosphaeria ITS sequences contained 529 positions. Of the 503 characters included in analysis, 284 were variable and 219 were constant. Among the variable sites, 209 were parsimony infor-

\footnotetext{
${ }^{2}$ The original descriptions of T. tocklaiensis shows microawns of various shapes, whereas Pirozynski and Hodges (1973) show the microawns of T. tocklaiensis to be L-shaped. We have accepted the original description for this key.
}

mative. The heuristic search identified two equally parsimonious trees, each 872 steps long, which differed only in their placement of Chaetosphaeria dilabens Réblová et W. Gams. The strict consensus tree showed 11 clades, which were supported by bootstrap values higher than $55 \%$ (FIG. 4). The two representative taxa of Thozetella grouped next to Striatosphaeria codinaeaphora and Codinaeopsis gonytrichoides with this clade having a bootstrap support of less than $55 \%$ (Fig. 4). A branch supporting the majority of Chaetosphaeria species has high bootstrap support $(92 \%)$. The genetic distances of all Chaetosphaeria species excluding outgroups and excluding Thozetella were $0.0-25.5 \%$; the genetic distances of Thozetella and Chaetosphaeria species were 11.0-31.8\% (details not shown).

The aligned dataset of specimens of Thozetella plus two outgroups contained 494 positions excluding indel scores. Of the 467 characters included in the analyses, 133 were variable and 334 were constant. Among the variable sites, 66 were parsimony informative. Intraspecific genetic distances were low (0$0.7 \%)$, whereas interspecific genetic differences were 2.3-8.5\%. The lowest interspecific genetic distance was observed between T. acerosa and T. boonjiensis (2.3 and 2.4\%). The next closest species was T. gigantea, which differed from these two species between 4.1 and $4.4 \%$. The greatest genetic distance was observed between T. gigantea and T. queenslandica (8.2 and $8.4 \%$ ), while T. falcata differed from all other species between 4.9 and $6.4 \%$. When indels were excluded from analysis, three most parsimonious trees were obtained, each 189 steps long and differing only in the arrangement of terminal branches within the clade representing Thozetella falcata. The strict consensus tree of three most parsimonious trees shows two clades and five subclades (FIG. 5). Thozetella boonjiensis and T. acerosa are sister clades and group next to $T$. gigantea. This tree also shows $T$. falcata and T. queenslandica to be sister clades. Bootstrap support is generally moderate to high (82$100 \%$ ) but two branches have bootstrap values of only 56 and 59\% (FIG. 5). One of these branches (viz. the branch supporting $T$. queenslandica and $T$. falcate) collapsed to form a polytomy when the data were re-analyzed with indel scores included (not shown).

\section{DISCUSSION}

Relationship of Thozetella and Chaetosphaeria.Analysis of ITS sequence data associated the anamorph genus Thozetella with the ascomycete genus Chaetosphaeria (FIG. 4). Reblova and Winka (2000) discussed the phylogeny of Chaetosphaeria and used 


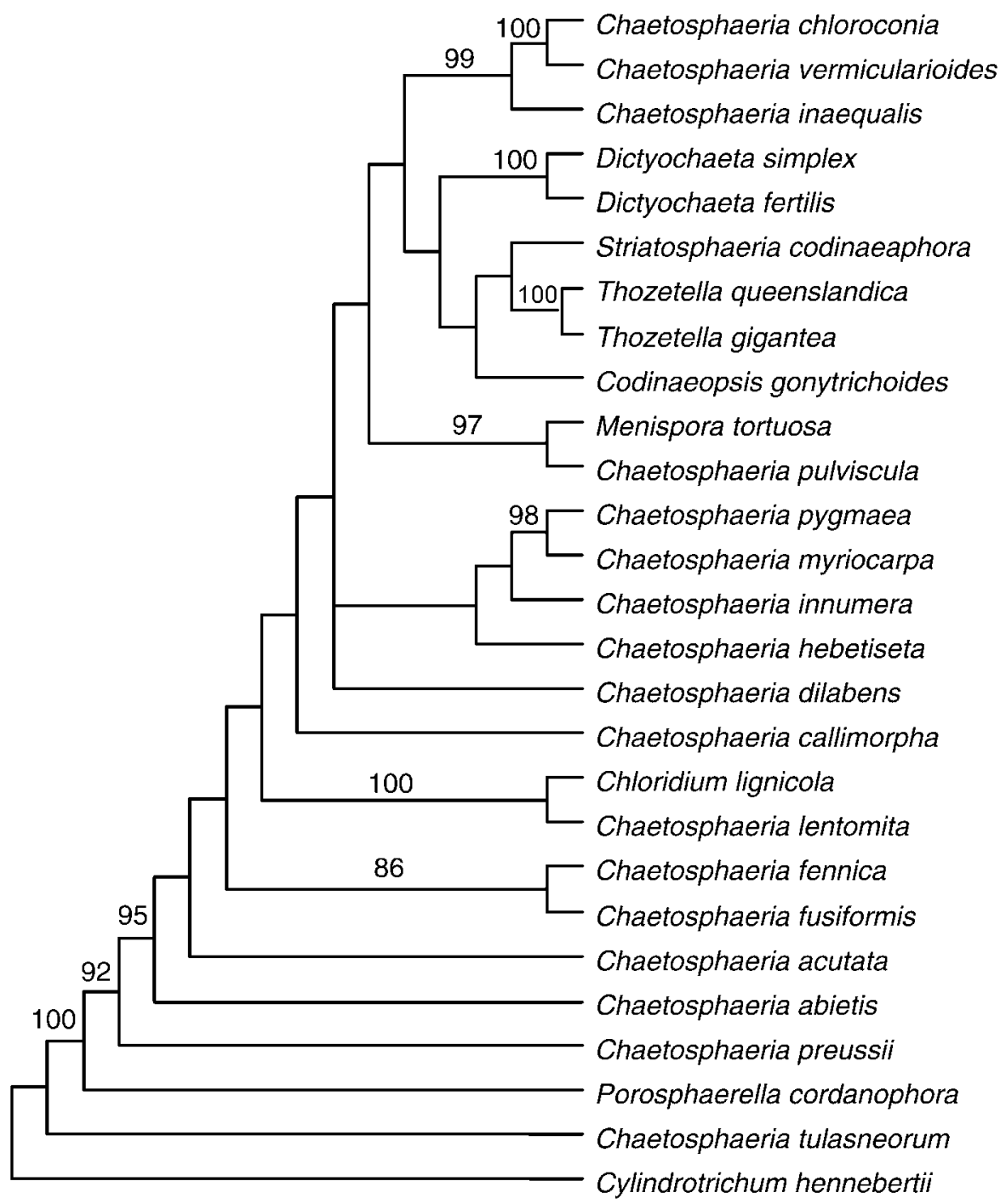

FIG. 4. Phylogenetic relationships among species of Chaetosphaeria and its anamorphs based on ITS rDNA sequences. The phylogram, which is rooted by the outgroup method, depicts the strict consensus tree of five most parsimonious trees. Significant bootstrap values $(>55 \%)$ are given above branches.

two separate genomic regions in their analysis. Our ITS rDNA analysis was conservative and, hence, the resulting strict consensus tree was less resolved than that of Reblova and Winka (2000). Subgroups 1A and 1B inferred by Reblova and Winka (2000) clustered together, and the two Thozetella sequences inserted in this clade (FIG. 4). In addition to two teleomorph genera, Chaetosphaeria pulviscula and Striatosphaeria codinaeaphora, subgroup 1A includes the anamorphs Dictyochaeta, Menispora and Codinaeopsis, which are characterized by producing oblong, fusiform, often curved conidia with terminal setulae (Reblova and Winka 2000). The genus Thozetella shares these morphological characteristics and, therefore, morphological data are consistent with the results of ITS sequence analysis, despite the low bootstrap support values obtained for those clades. The teleomorphs of individual Thozetella species remain unknown because cultures did not produce ascomata and nucleotide divergence among available Thozetella and Chaetosphaeria sequences consistently was greater than $11 \%$.

Phylogenetic analysis of Thozetella species. - This study applied both phylogenetic and morphological species recognition (Taylor et al 2000) and both were congruent. For example, sequence analysis of ITS rDNA supported recognition of the morphological species as five distinct clades (FIG. 5). The strict consensus tree of the Thozetella sequences suggests that they are a strongly supported monophyletic group (100\%, Fig. 5). Two main sister clades are resolved 


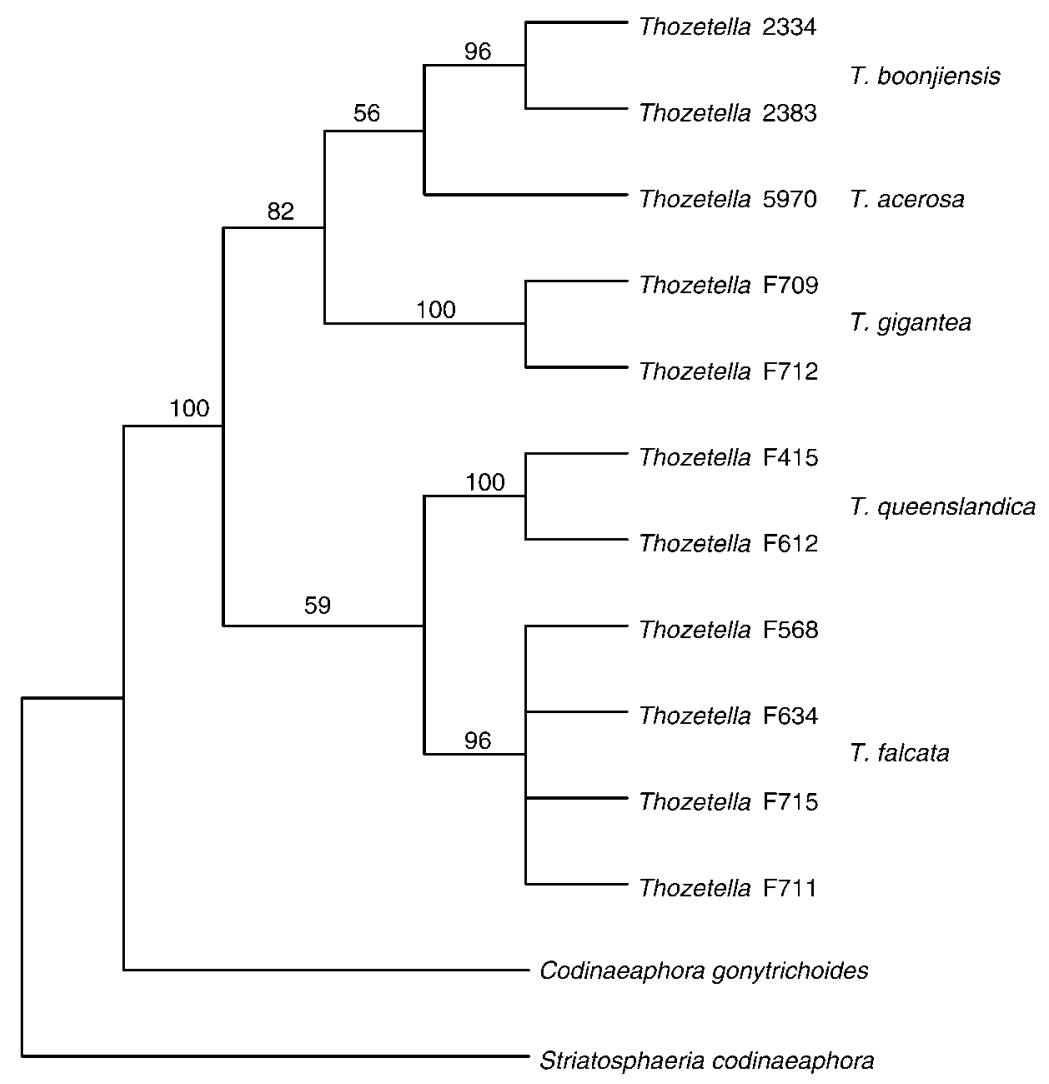

FIG. 5. Phylogenetic relationships among species of Thozetella based on ITS rDNA sequences. The phylogram, which is rooted by the outgroup method, depicts the strict consensus tree of three most parsimonious trees. Significant bootstrap values $(>55 \%)$ are given above the branches.

with the clade grouping T. acerosa, T. boonjiensis and T. gigantea showing a moderately high bootstrap value ( $82 \%$, Fig. 5). These species share the same basic microawn shape and predominant conidiomatal configuration but differ in microawn length (TABLE II). In addition to their morphological similarity, they also have the smallest interspecific genetic differences observed in our study.

Despite its relatively low bootstrap value, the clade supporting T. acerosa and T. boonjiensis remained stable when indel scores were included (not shown). The other clade, which includes T. queenslandica and T. falcata, was weakly supported (bootstrap value 59\%, FIG. 5) and the branch supporting this clade collapsed when indel scores were included in analysis. Because insertions and deletions are thought to be the primary source of ITS variation in fungi (Hibbett 1992), the close relationship between T. queenslandica and $T$. falcata cannot be inferred with as much confidence as that of the species in the first clade. This uncertainty is mirrored in the morphology of these species and the moderately high genetic distance (6.2 and 6.4\%). Although T. queenslandica and T. falcata share a similar microawn shape (i.e., curved), their basic conidiomatal configurations differ (TABLE II). Including ITS sequences of other species and testing the concordance of more than one gene genealogy might help to resolve the phylogeny of Thozetella in the future (Taylor et al 2000).

Species delimitation based on morphology.-Re-examination of morphological characters following ITS sequence analysis suggested that basic microawn morphology, such as L-shaped versus curved, microawn length and basic conidiomatal configuration, such as sporodochia versus synnemata, are key characters in species delimitation. Conidium and conidiophore morphology and dimensions, which are usually important characters in differentiating anamorphic fungi species, can play only a secondary role in Thozetella due to their similarity among some species (TABLE II). With one exception, each new species in our collection differs from the most similar, previously described taxa in at least one key criterion and usually by one or more secondary characteristics (TABLE II, Key). Thozetella boonjiensis does not differ from $T$. nivea by a key taxonomic character but by three other characters, namely conidial length, conidial width and finer microawn morphology (TABLE II, Key). 
Comparison of fruiting structures from cultures and from leaves. - One of the criticisms raised by Sutton and Cole (1983) in delimiting Thozetella species was that new species had been described from few specimens and in a number of instances were known only either from culture or from natural substrata. Sutton and Cole (1983) reported that there was a considerable increase in conidial size and a moderate increase in microawn length, as well as greater variation of conidiomata morphology in cultures of T. effusa, as compared to those developing on natural substrata. In contrast, Agnihothrudu (1958) and Castañeda Ruiz (1984) observed minimal size variation in conidia and microawns of T. tocklaiensis and T. havanensis from natural substrata and from cultures.

In our study, cultures were available for all five species and for three of these specimens also could be studied from natural substrata (TABLE I). A comparison of microawn and conidial dimensions revealed some variation among specimens derived in vitro and from natural substrata, but these differences were not statistically significant. Similarly, microawn length appeared to decrease in cultures of all species with increasing temperature and with dark treatment (data not shown), but no statistical significance was detected. In contrast, conidial length differed significantly among cultures grown under different conditions. This difference could be attributed to a marked increase in conidial length in cultures of $T$. gigantea when grown at $25 \mathrm{C}$ rather than at $20 \mathrm{C}$. Overall, microawn and conidial dimensions did not differ significantly on CMA and PCA. However, temperature preferences as observed by different growth rates (FIG. 3) and peaks in sporulation (TABLE IV) might provide additional taxonomic information.

The identification of many anamorphic genera (e.g., Cylindrocladium, Cylindrocladiella and Fusarium) has been based almost solely on cultural characteristics under standard conditions (e.g., Joffe 1986, Crous et al 1992, Crous and Wingfield 1994). The same approach has been suggested for Thozetella (Sutton and Cole 1983) and may be particularly useful if conidiomatal configuration is to be utilized as a taxonomic character. Specimens of the same Thozetella species have been observed to differ in the type of conidiomata formed even when derived from the same substratum (Castañeda Ruiz pers comm), but conidiomatal configuration remained basically stable in cultures of the five species investigated (TABLE IV). Although long-term stability was not evaluated, we recommend that Thozetella species be characterized routinely on CMA that includes a sterilized banana leaf, after incubation at $20 \mathrm{C}$ for $2 \mathrm{wk}$. This recommendation is based on the slow development of conidiomata in some of the species and differs from oth- er anamorphs where assessment usually is undertaken after 7 d (e.g., Fisher et al 1982, Samuels and Brayford 1990, Crous et al 1992).

\section{ACKNOWLEDGMENTS}

We gratefully acknowledge these institutions for financing this project: the Centre for Research of Fungal Diversity at the Department of Ecology and Biodiversity; The University of Hong Kong; the Cooperative Research Centre for Rainforest Ecology and Management; and the School of Tropical Biology, James Cook University. Kylie McKenzie (Trinity Anglican School, Cairns) contributed to the assessment of cultures under different growing conditions as part of a student research scheme. B.P. thanks N. Tucker for access to one of the collection sites, C. Pearce and I. Steer for their company on collection trips, H. Leung for providing support with photography, M. Harrington for advice on phylogenetic analysis and useful comments on the manuscript and L. Jones and M. Pye for assistance with technical aspects. We especially thank R. Castañeda Ruiz for sharing his taxonomic knowledge and experience. Two anonymous reviewers are thanked for their valuable comments.

\section{LITERATURE CITED}

Agnihothrudu V. 1958. Notes on fungi from north-east India. I. A new genus of Tuberculariaceae. Mycologia 50: 570-579.

Bills GF, Polishook JD. 1994. Abundance and diversity of microfungi in leaf litter of a lowland rain forest in Costa Rica. Mycologia 86:187-198.

Booth C. 1971. Methods in microbiology. Vol. 4. London, UK: Academic Press. 795 p.

Castañeda Ruiz RF. 1984. Nuevos taxones de Deuteromycotina: Arnoldiella robusta gen. et sp.nov., Roigiella lignicola gen. et sp. nov., Sporidesmium pseudolmediae sp.nov., y Thozetella havanensis sp. nov. Revista del Jardin Botanique Nacional, Universidad de Havana 5:5787.

Castañeda Ruiz RF, Arnold GRW. 1985. Deuteromycotina de Cuba. I. Hyphomycetes. Revista del Jardin Botanique Nacional, Universidad de Havana 6:47-67.

Crous PW, Phillips AJW, Wingfield MJ. 1992. Effects of cultural conditions on vesicle and conidium morphology in species of Cylindrocladium and Cylindrocladiella. Mycologia 84:497-504.

Crous PW, Wingfield MJ. 1994. A monograph of Cylindrocladium, including anamorphs of Calonectria. Mycotaxon 51:341-435.

Felsenstein J. 1985. Confidence limits on phylogenies: an approach using the bootstrap. Evolution 39:783-791.

Fisher NL, Burgess LW, Toussoun TA, Nelson PE. 1982. Carnation leaves as a substrate and for preserving cultures of Fusarium species. Phytopathology 72:151-153.

Gams W, Hoekstra ES, Aptroot A. 1998. CBS Course of Mycology. 4th ed. Delft, The Netherlands: Centraalbureau voor Schimmelcultures. $165 \mathrm{p}$.

Hibbett DS. 1992. Ribosomal RNA and fungal systematics. 
Transactions of the Mycological Society of Japan 33: 533-556.

Joffe AZ. 1986. Taxonomic problems of the genus Fusarium. In: Joffe, AZ, ed. Fusarium species: their biology and toxicology. New York, USA: J. Wiley and Sons. 588 p.

Johnston A, Booth C. 1983. Plant pathologist's pocketbook. 2nd ed. Slough, England: Commonwealth Agricultural Bureau. 439 p.

Kirby JJH, Webster J. 1990. A particle plating method for analysis of fungal community composition and structure. Mycological Research 94:621-626.

Kirk PM. 2001. Ainsworth \& Bisby's dictionary of the fungi. 9th ed. Wallingford, UK: C.A.B. International. 672 p.

Kuntze O. 1891. Revisio generum plantarum. A. Felix, Leipzig, Germany. 1011 p.

Matsushima T. 1971. Microfungi of the Solomon Island and Papua New Guinea. Kobe, Japan: Matsushima Fungus Collection. 78 p.

Mercado-Sierra A, Holubova-Jechova V, Mena Portales J. 1997. Monografie XXIII. Hifomycetes demaciaceos de Cuba. Enteroblasticos. Torino, Cuba: Museo Regionale Di Scienze Naturali. p 352-354.

Nag Raj TR. 1976. Miscellaneous microfungi. I. Canadian Journal of Botany 54:1370-1376.

Paulus B, Gadek P, Hyde KD. 2003. Estimation of microfungal diversity in tropical rain forest leaf litter using particle filtration: the effects of leaf storage and surface treatment. Mycological Research 107:748-756.

Pirozynski KA, Hodges CS. 1973. New Hyphomycetes from South Carolina. Canadian Journal of Botany 51:157173.

Reblova M, Winka K. 2000. Phylogeny of Chaetosphaeria and its anamorphs based on morphological and molecular data. Mycologia 92:939-954.
Samuels GJ, Brayford D. 1990. Variation in Nectria radicicola and its anamorph Cylindrocarpon destruens. Mycological Research 94:433-442.

Sivichai S, Jones EBG, Hywel-Jones N. 2002. Fungal colonisation of wood in a freshwater stream at Tad Ta Phu, Khao Yai National Park, Thailand. Fungal Diversity 10: 113-129.

Smith DR, Stanosz GR. 1995. Confirmation of two distinct populations of Sphaeriopsis sapinae in the North Central United States using RAPDs. Phytopathology 85: 699-704.

SPSS. 2001. Chicago, Illinois, USA: Lead Technologies Inc.

Sutton B, Cole GT. 1983. Thozetella (hyphomycetes): an exercise in diversity. Transactions of the British Mycological Society 81:97-107.

Swofford DL. 2002. PAUP*. Phylogenetic analysis using parsimony (*and other methods). Sunderland, Massachusetts, USA: Sinauer Associates.

Taylor JW, Jacobson DJ, Kroken S, Kasuga T, Geiser DM, Hibbett DS, Fisher MC. 2000. Phylogenetic species recognition and species concepts in fungi. Fungal Genetics and Biology 31:21-32.

Waipara NW, Di Menna ME, Cole ALJ, Skipp RA. 1996. Characterisation of Thozetella tocklaiensis isolated from the roots of three grass species in Waikato pastures, New Zealand. New Zealand Journal of Botany 34:517522.

White TJ, Bruns TD, Lee S, Taylor J. 1990. Amplification and direct sequencing of fungal ribosomal DNA genes for phylogenetics. In: Innis, MA, Gelfand, DH, Sninsky, J J and White, TJ, eds. PCR Protocols. San Diego, USA: Academic Press. p 315-322.

Yanna, Ho WH, Hyde KD. 2002. Fungal succession on fronds of Phoenix hanceana in Hong Kong. Fungal Diversity 10:185-211. 